\title{
The English in Sydney
}

\section{James Jupp}

The most famous Englishman in Australian history, Captain James Cook, missed the entrance to Sydney Harbour during the night. He and fellow Englishman, Sir Joseph Banks, committed future explorers to the less promising site of Botany Bay.

Nearly 20 years later, Sydney was founded by the British government as a penal colony. Although there was an established Aboriginal population, they remained on the periphery and were gradually reduced by disease and displacement, a fate suffered by others further out as exploration and settlement proceeded. In contrast to New York, which was established by the Dutch, or Boston, which became predominantly Irish, Sydney was seen from the beginning as an 'English' town. This was despite its growing connections with the Pacific and the presence among its soldiers and convicts of some Scots and many Irishmen. The majority of transported convicts were English, the Church of England was the established religious faith and Catholicism was strictly limited by official control.

Visitors were describing the English character of the city for at least the first 50 years after 1788, noting the traditional English appearance of the churches, while overlooking the convict barracks. The barracks, the Parramatta female factory, churches at Windsor and Liverpool and St James in the city, were designed by the Gloucestershire former convict Francis Greenway (1777-1837) on Georgian English models. A later eminently ‘English’ building was Government House, built in the form of a Victorian neo-classical castle, complete with castellated stables.

First-generation Sydneysiders, other than the disappearing Aborigines, were predominantly English, although the Queen arrived in 1791 with Irish convict passengers. Between 1788 and 1840, 80,000 English convicts were transported to New South Wales, with the greatest numbers coming between 1825 and 1835. Others were regarded with suspicion, particularly the rebellious Catholic Irish. The first census, in 1828, only gives details of free or convict status and ship of arrival. But the fuller New South Wales Census of 1846 shows the gap narrowing, with 57,349 born in England compared with 47,547 born in Ireland and 14,406 born in Scotland. Between 1840 and 1870 there were more Irish than English assisted migrants and the balance did not turn in favour of England until the 1870s. These figures include settlers in areas that today are parts of Victoria and Queensland.

The surge in Irish convict transportation and free migration by the late 1840s reduced English domination, but many Irish settled in or were assigned to rural areas rather than Sydney. Political leaders, especially Sir Henry Parkes, campaigned against Irish immigration over the next thirty years. By mid-century the English character of Sydney was certainly under threat. However 
surges of English immigration in the 1880s, between 1910 and 1914, again in the 1920s and, most of all, in the 1950s and 1960s, sustained the English-born as the largest single immigrant group, while the Irish-born faded away to a small minority, albeit with a large number of descendants.

\section{English founders and leaders}

English Protestants were able to maintain control over most institutions for the first two generations, as manhood suffrage and democratic institutions were not fully developed until the late 1850s. Evangelical Anglicanism was strong, as it still is, and was supplemented by increasing numbers of English Methodists, Congregationalists and Baptists. The Scottish element in Sydney was much smaller than in growing Melbourne and such religious and ethnic tension as existed in Sydney was between the English, predominantly Anglican, and the Irish, predominantly Catholic. Indeed religious sectarianism between Catholics and Protestants remained a feature of Sydney life well into the twentieth century.

However electoral politics was not always dominated by the English majority in the nineteenth century. The oldest colony and city produced only eight English-born premiers between 1840 and 1914. Of this group, three were born in London, two in Lancashire, one at sea to Lancashire parents, one in Warwickshire and only one other in rural England, where so many assisted migrants came from. Sir Henry Parkes (1815-1896) was by far the most important and best known. He was born in Warwickshire and retained an English accent throughout his life, which often attracted comment. Others of significance included Sir John Robertson (1816-1891), and two Labor premiers, WA Holman (1871-1934) and James McGowan (1855-1922). More were born in Australia or Ireland than might have been expected.

Underrepresented among elected leaders, the English-born were prominent among governors nominated by the British government, all of whom were born overseas. Thirteen governors between 1788 and 1913 were born in England, and others of English origin were born elsewhere in the British Empire, in Canada, Malta or India. Several were born in Scotland or Ireland. The early governors had almost absolute power. From the 1840s they were limited by elected bodies and from 1901 their role became increasingly decorative. Most colonial governors remained in Australia for fewer than seven years.

Of those undoubtedly English, at least eight were born in London and three in the southwest, in Cornwall, Plymouth and Bristol. None were from the growing industrial areas of the North and Midlands. Most had an aristocratic background or were awarded knighthoods. The unfortunate William Bligh and the founding governors Arthur Phillip and Philip Gidley King were exceptions. All three were naval officers and Sydney was a minor posting between 1788 and 1817. Later English appointments were more prestigious, including three earls and two lords. 
Just as the office was becoming largely decorative, Sir Philip Game, born in London, startled Sydney by dismissing the government of Jack Lang in May 1932. Since then, as elsewhere in Australia, most New South Wales governors have been Australian-born.

The early settlers of Sydney were divided between convicts and free and between English and Irish. The second division was transformed into one between Protestants and Catholics, with the active recruitment of Presbyterians from Scotland by Reverend John Dunmore Lang after 1824 and the appointment of two Catholic chaplains in 1819. Essentially, free English Protestants were accepted by the social and political establishment while others, including emancipated convicts, were ostracised or looked on with suspicion. Indeed, religious sectarianism between Catholics and Protestants continued as a feature of Sydney life well into the twentieth century.

Nevertheless in a raw new society with limited human resources, the English did not monopolise all positions of power, influence and wealth. In a city with limited manufacturing or landed property, wealth and influence came from politics and from providing services to the city and the large rural economy, through retail outlets, media, construction, utilities, import and export. Among English-born who achieved fame or fortune in these areas were politicians such as Sir Henry Parkes, WA Holman and Joseph Cook; retailers, brewers and media owners such as John Norton, Marcus Clark, Anthony Hordern, John Fairfax and John Tooth; and entrepreneurs like Mary Reiby, Ben Boyd, John Macarthur or Thomas Mort. In social and charitable work, eminent Englishmen and women included the philanthropist Caroline Chisholm and clergymen such as Samuel Marsden, Bishop Broughton and Bishop Polding. The numbers of notable English immigrants were large during Sydney's first century and then gradually reduced, as Sydney-born descendants replaced their English ancestors and the immigrant population declined in relative and then absolute size.

\section{Immigration after the convicts}

Australia has experienced consistent immigration from England since 1788 and an appropriate proportion of this has gone to Sydney. In 1846 the English-born population of New South Wales was 30 per cent. By 1891 the English-born proportion in New South Wales had dropped to 13.3 per cent, the lowest of any Australian colony, altogether 150,000 and twice the number of the Irish-born. However assisted immigration was focussed on rural settlement at least until the 1870s. Many English migrants became small farmers and agricultural labourers, especially in northern New South Wales. After 1870 assistance broadened out to include miners and industrial craftsmen, but many of these went to the Hunter coalfields. Free immigrants did come to Sydney, but as late as 1901 most free English immigrants in New South Wales lived outside the capital. In 1891 only 17 per cent of the metropolitan Sydney population were English-born. 
The main intake which did not benefit Sydney was in the gold rush years of the 1850s. Although New South Wales and Victoria each assisted 40,000 British immigrants in the 1850s, many drifted south towards the goldfields in Victoria. The great majority of unassisted immigrants, who were predominantly English, went directly to Victoria. For the next 40 years Melbourne was larger than Sydney.

The large New South Wales intake of almost 30,000 English migrants in the 1880s was followed by movement from depressed Melbourne to Sydney in the 1890s and then by assisted migration between 1910 and 1914. After World War I there were further large assisted intakes between 1920 and 1929, terminated by the world depression. So a high proportion of English migrants settled between 1880 and 1930 and this is reflected in the rapid growth of many Sydney inner suburbs south of the Harbour. Already, by 1891, suburbs with high numbers of English-born included Auburn, Granville, Concord, Hurstville, Leichhardt and Rockdale.

Sydney was always the most Anglican major city in Australia and this was very clear by 1901 . Church of England adherents in 1901 had absolute majorities in Five Dock (62.5 per cent), Ashfield, Auburn, Bankstown, Bexley, Botany, Burwood, Cabramatta, Concord, Darlington, Drummoyne, Enfield, Erskineville, Fairfield, Glebe, Hurstville, Kogarah, Liverpool, Manly, Mosman, Newtown, North Sydney, Rockdale, Rookwood, Ryde, St Peters, Strathfield and Vaucluse. The majority of these were respectable working class and lower middle class suburbs, expanding along the new railway routes built in the 1880s. They did not change their character much before the 1960s.

The largest intake, between 1950 and 1970, was distributed around Australia and Sydney got rather less, proportionately, than Melbourne, Perth and Adelaide, though more than Brisbane. Since 1970 English migration has dropped from almost half the nationwide intake to less than 10 per cent in 2000 .

\section{The English inheritance}

That Sydney was largely founded by the English is still evident in place names, buildings and street layouts, apart from the obvious point that 80 per cent speak English as their mother tongue and that Anglicanism is still the second largest religion, at least in nominal allegiance.

English-inspired place names can be divided between those named after prominent Englishmen from the founding years and place names from English originals. Both are as evident as Aboriginal names or even place names from other parts of the British Isles. At least 50 suburban names are derived directly from 20 English counties, of which the largest numbers are from Kent, Surrey, and London. Among the best known are Surry Hills, Croydon, Hornsby, Penrith, Chipping Norton, Brighton-le-Sands, Bexley, Canterbury, Ryde, Kensington, Epping , St Ives, Lewisham and Penshurst. As in London, the victory of Waterloo is enshrined in a suburb name 
and ten streets. City centre street names commemorate British and colonial leaders and English politicians are also remembered in suburbs such as Beaconsfield, Castlereagh, Liverpool, Asquith and Rosebery. Queen Victoria, as elsewhere, has about 100 streets and road sections named after her, including the long and congested Victoria Road, and the elegant Victoria Street in Potts Point.

The physical inheritance of early English settlement is apparent in the small number of surviving buildings designed by Francis Greenway. But a much larger inheritance remains from buildings erected in the later nineteenth century, especially during the immigration boom of the 1880s. Large numbers of Victorian Gothic churches, including the Anglican and Catholic cathedrals, remain alongside town halls, post offices and commercial buildings in the same solid styles as in Manchester or Birmingham. The University of Sydney's older buildings are in the same Gothic architectural tradition.

Sydney also resembles English cities in its chaotic street layout. This contrasts with the 'checkerboard' or grid pattern of Melbourne, Adelaide and Perth and most contemporary North American cities. While the central business district and North Sydney have been transformed into multistorey skyscraper replicas of New York and Chicago, the surrounding older suburbs are still reminiscent of English cities built in the Victorian period. The main difference lies in the decoration of terrace house fronts with cast iron balconies and the frequency of single-storey cottages, which becomes even more obvious in the newer suburbs.

Sydney now covers a vast area comparable to London, but with more spacious layouts, more unattached homes and a much lower population density. In its more favoured beachside and North Shore suburbs, it reaches levels of affluence very unusual inside English cities, but found outside them in surrounding districts like Surrey, Berkshire and Cheshire. No major English cities have a beach front except the large seaside towns of Brighton, Bournemouth and Blackpool, and nothing can compare with Sydney's harbour and ocean suburbs. Sydney looks like an English city in its century-old inner city, but not in the areas in which most people live today.

\section{Anglo but not English - Sydney today}

Few people today would describe Sydney as an 'English’ city, including the English immigrants who live here. But the English are still the largest overseas-born group, if hardly constituting a community. They numbered 145,260 in the Sydney Statistical Division in 2006. This is a modest 3.5 per cent of a population of four million and the proportion has been declining for years.

English impact is not as marked as in Perth or Adelaide. But Sydney has the largest and richest Anglican diocese in Australia which is probably livelier and more influential than many of its English counterparts and keeps English links and traditions alive. The English sports of cricket and rugby league draw in the largest sporting crowds, although soccer is much less Anglicised 
than in Perth or Adelaide. What the English lack in Sydney, as elsewhere, is a network of national social clubs. It seems they feel no great need for them.

When we look below the surface of birthplace and break down the vast Statistical Division into its component municipalities, a better picture of the spread of 'Englishness' emerges. Important indicators, other than birthplace, include ancestry and religious adherence. These are selfdescriptions but useful nevertheless. Those born in England are, with a few exceptions from the major intake of the 1920s, mainly assisted immigrants from the massive postwar intake which reached its peak in the 1960s and has now declined to less than 10 per cent of arrivals. More recent arrivals have paid their own fares since 1983 and are more likely to be highly skilled and educated than those who came before them. The great majority of new immigrants from the United Kingdom were English, with Scots numbering less than 15 per cent, and a smaller intake from Ireland. This is a different picture from the nineteenth century arrivals.

In contrast to Adelaide, Perth and parts of Melbourne, there are few visible concentrations of English migrants in Sydney. The English do seem to favour beachside suburbs and those in the hilly periphery. Thus the highest proportions of English-born are in Manly, Mosman, North Sydney, Pittwater, Blue Mountains, Camden, Gosford, Ku-ring-gai, Warringah and Woollahra. One exception is Leichhardt, but this may be influenced by the proximity of the University of Sydney. In these local government areas the proportion born in England ranges from 5 to 8 per cent. At the opposite extreme are industrial suburbs with high numbers of non-British migrants, including Auburn, Bankstown, Canterbury, Fairfield, Holroyd, Liverpool, Rockdale and Strathfield, where less than two per cent were English-born. In real estate terms the English seem to have picked the eyes out of the most attractive locations in Sydney. They have not settled in the same suburbs as their predecessors of a century ago.

Far more Sydneysiders have English ancestors than are represented in the above figures. Many are of mixed British origins, leading to the contested term 'Anglo-Celtic' which has been banned in official usage for years by the New South Wales government. Two Census measures of 'Englishness' are ancestry and Anglicanism. Both, while problematic, are quite useful. As the English have been settling Sydney since 1788, the chances of having English ancestors or adhering to the dominant English religion are very high. The figures for 2006 show a similar pattern to those for English immigrants. The strongest support for Anglicanism is on the outskirts and the North Shore. Catholics are the largest denomination in almost all Sydney council areas and form 28 per cent in the entire Sydney area, compared with only 18 per cent for Anglicans (at 740,000). But Anglican followings of 25 per cent or more can be found in Camden, Campbelltown, Gosford, Hawkesbury, Ku-ring-gai, Manly, Mosman, Penrith, Pittwater, Sutherland, Warringah, Wollondilly and Wyong . Once again, with the exception of parts of Penrith and Campbelltown, these are favoured beachside and outer suburban middle class 
districts. Anglican avoidance of 'ethnic' industrial areas and inner suburbs is most apparent in Ashfield, Auburn, Burwood, Canterbury, Fairfield, Marrickville, Strathfield and the City of Sydney. As Anglicans have long been notorious for low levels of church attendance, this means that they have little active presence in the more multicultural parts of the city.

A further and more recent Census indicator of 'Englishness' is ancestry, where up to two origins are reasonably allowed, to cater for the very large number whose ancestors have crossed ethnic or religious boundaries. Here respondents are allowed to call themselves 'Australians' if they wish. In the Sydney Statistical Division in 2006 slightly more than 1,200,000 described themselves as Australians and one million as English. These include people calling themselves English- or Anglo-Australians, including some New Zealanders or South Africans. The pattern for claiming English descent follows roughly the same lines as for British migrants or Anglicans, though in larger proportions. Suburbs where over one in three claim English ancestry include Blue Mountains, Camden, Hawkesbury, Hornsby, Hunters Hill, Ku-ring-gai, Lane Cove, Manly, Mosman, North Sydney, Pittwater, Sutherland, Warringah, Wollondilly and Wyong. These are either on the outer periphery or are what used to be called 'dress circle' suburbs on the North Shore or beside the beach.

The English have come a long way since they made up the majority of convicts.

What these no doubt inadequate figures suggest is that many English Australians, Anglicans and immigrants are likely to be firmly middle class, well off and politically conservative. Workingclass English enclaves in places like Daceyville undoubtedly exist. There are still many areas in which English-descended 'battlers' are quite numerous, such as Penrith, Campbelltown, Hurstville, Kogarah, Blacktown and Randwick. In 1910 Sydney was officially proclaiming itself the 'second city of the Empire', which ignored Glasgow, not to mention Bombay and Calcutta. Today it might call itself the second most English city in the world, as it is larger than Birmingham and more English than Toronto or any comparable American city. But these comparisons no longer matter in the way they did only a century ago.

James Jupp is Director of the Centre for Immigration and Multicultural Studies in the Australian Demographic and Social Research Institute at the Australian National University in Canberra

\section{References}

James Jupp, The English in Australia, Cambridge University Press, Melbourne, 2004

James Jupp, (ed), The Australian People, Cambridge University Press, Melbourne, 2001 